\title{
Effect of Integrated Nutrient Management on Growth Parameters of Fennel (Foeniculam valgare Mill.) in Inceptisol
}

\author{
Y.V. Singh ${ }^{1}$, D.K. Srivastava ${ }^{3}$, Pavan Singh $^{1}$, S.K. Varma ${ }^{2}$, \\ A.K. Kanthle ${ }^{1}$ and D. Mishra ${ }^{1}$
}

${ }^{1}$ Department of Soil Science and Agricultural Chemistry, ${ }^{2}$ Department of Agronomy, Institute of Agricultural Sciences, Banaras Hindu University, Varanasi 221005, India

${ }^{3}$ Council of Science \& Technology, U.P. Lucknow - 226018 (U.P.), India

*Corresponding author

\begin{tabular}{|c|c|}
\hline & A B S T R A C T \\
\hline $\begin{array}{l}\text { K e y w o r d s } \\
\text { STCR-IPNM, Fennel, } \\
\text { Plant height, Number of } \\
\text { branches, Fresh weight } \\
\text { and dry weight (gm) etc. }\end{array}$ & \multirow{3}{*}{$\begin{array}{l}\text { Studies on soil test crop response based on integrated plant nutrient } \\
\text { management system (STCR-IPNM) were conducted for the growth } \\
\text { parameters of fennel on Inceptisol of agricultural research farm, Banaras } \\
\text { Hindu University, Varanasi during Rabi } 2017-18 \text {. Objective is to study the } \\
\text { effect of integrated nutrient management on growth parameters of Fennel in } \\
\text { Inseptisol. Integrated application of N.P.K 120-60-45 kg ha }{ }^{-1} \text { with F.Y.M } \\
10 \mathrm{tha}^{-1} \text { in strip IIIrd showed higher values of all the growth parameters } \\
\text { attributes, viz., - plant height, number of branches/plant, fresh weight and } \\
\text { dry weight of following strip IInd and strip Ist. }\end{array}$} \\
\hline Article Info & \\
\hline $\begin{array}{l}\text { Accepted: } \\
\text { 10 February } 2018 \\
\text { Available Online: } \\
10 \text { March } 2018\end{array}$ & \\
\hline
\end{tabular}

\section{Introduction}

Fennel (Foeniculum vulgare Mill.) is one of popular seed spice in India mainly grown in rabi season, locally known as saunf belongs to the family Apiaceae (Umbelliferae). Fennel is native to Southern Europe and Mediterranean region. It is a perennial, but is grown as annual or biannual. It is cultivated throughout the temperate and subtropical regions of the world for its aromatic seeds which are used for culinary purpose. Plants have dark green or bronze wispy leaves with the yellow flowers on compound umbels and are cross pollinated. It is tall, hardy and erect growing herb and grows from $90-150 \mathrm{~cm}$. Among the aromatic plants, we consider the fennel, in which its seeds have several uses (culinary, pharmaceutical, etc).

Fennel is also highly recommended for diabetes, bronchitis and chronic coughs, treatment of kidney stones, and is considered to have diuretic, stomachic and galactogogue properties. In India, it is mainly cultivated in the states of Gujarat and Rajasthan and to some extent in Uttar Pradesh, Bihar, Madhya Pradesh, Punjab and Haryana. In India, area under fennel was 41368 ha with production of $58265 \mathrm{t}$ and productivity of $1.40 \mathrm{t} \mathrm{ha}^{-1}$ in 
2010-11 (SBI, 2011). The farm yard manure (FYM) seems to be directly responsible in increasing crop yields either by accelerating the respiratory process by increasing cell permeability by hormone growth action or by combination of all these processes.

It supplies nitrogen, phosphorus and potassium in available forms to the plants through biological decomposition. Indirectly it improves physical properties of soil such as aggregation of soil, permeability and water holding capacity. It is prepared from the dung of farm animals and contains all the essential elements.

\section{Materials and Methods}

To assess the validation of fertilizer equation for fennel developed by Soil test Crop Response based on Integrated Plant Nutrient Management (STCR - IPNM) were conducted for the growth parameters of Fennel, on Inceptisol of Agricultural Research Farm, Banaras Hindu University, Varanasi during Rabi 2017-18.

\section{Physico-chemical experimental soil}

properties

of

The soil of the experimental site was sandy loam in texture with predominance of kiolinite type of clay minerals which taxonomically categorized under the great group Typic Haplustepts (old alluvium).

Soil of experimental field had $166 \mathrm{~kg} \mathrm{ha}^{-1}$ alkaline permanganate oxidizable N (Subbiah and Asija, 1956), $14 \mathrm{~kg} \mathrm{ha}^{-1} 0.5 \mathrm{~N}$ sodium bicarbonate extractable $\mathrm{P}$ (Olsen et al., 1954), $146 \mathrm{~kg} \mathrm{ha}^{-1}$ neutral $1 \mathrm{~N}$ ammonium acetate exchangeable K (Hanway and Heidel, 1952) as described by (Jackson, 1973). 0.43\% organic carbon (Walkley and Black, 1934), $\mathrm{pH}$ of 7.50 and electrical conductivity of 0.43 $\mathrm{dSm}^{-1}$ in 1:2.5 soil to water (Jackson, 1973).

\section{Fertility gradient experiment}

Prior to test crop experimentation, fertility gradient experiment was conducted to create soil fertility gradient using 'inductive methodology' developed by Rama Moorthy et al., (1967).

For this purpose, field was divided into three equal rectangular strips and graded doses of fertilizer $\mathrm{N}, \mathrm{P}$ and $\mathrm{K}$ were applied as $\mathrm{N}_{0} \mathrm{~N}_{1} \mathrm{P}_{1} \mathrm{~K}_{1}$ (0-40-20-15), $\mathrm{N}_{0} \mathrm{~N}_{2} \mathrm{P}_{2} \mathrm{~K}_{2}$ (0-80-4035) and $\mathrm{N}_{0} \mathrm{~N}_{3} \mathrm{P}_{3} \mathrm{~K}_{3}$ (0-120-60-45) in strip I, strip II and strip III, respectively. Soil fertility gradient with respect to farmyard manure (FYM) was developed by applying FYM @ 0, 5 and 10 tonnes $\mathrm{ha}^{-1}$ in three strips across the fertilizer applied strips. This created distinct nine blocks (3 in each strip) in field receiving different nutrient doses. During winter 201718, preliminary exhaustive aromatic funnel crop (variety: African tall) was grown to stabilize soil fertility. Twenty-four soil samples $(0-15 \mathrm{~cm})$ from each strip were collected before sowing of exhaustive aromatic crop and analyzed for available nitrogen, by the alkaline permanganate method (Subbiah and Asija, 1956); available phosphorus, by Olsen et al., (1954) and available potassium, by the ammonium acetate method (Hanway and Heidal, 1952) as described by Jackson (1973).

\section{Growth parameters}

Plant height $(\mathrm{cm})$, number of branches, fresh weight and dry weight (gm) were taken 35,75 and 110 days after sowing and five randomly selected plants in each plot and the means were recorded.

The data were statistically analyzed according to a randomized block design and three replications. Mean, SD, Sem \pm and $\mathrm{CV}$ were calculated for significance amongst the treatments. 


\section{Test crop experimentation}

After fertility gradient experiment, each strip was divided into 24 plots to accommodate 24 treatments ( 21 treatments +3 controls) making total of 72 plots. Three blocks (comprising 8 treatments) were made within each strip. The experiment was laid out in fractional factorial randomized block design. The treatments comprised of selected combinations of four levels of nitrogen $(0,40,80$ and $120 \mathrm{~kg} \mathrm{~N}$ $\left.\mathrm{ha}^{-1}\right)$, phosphorus $\left(0,20,40\right.$ and $60 \mathrm{~kg} \mathrm{P}_{2} \mathrm{O}_{5}$ $\left.\mathrm{ha}^{-1}\right)$ and potassium $\left(0,15,30\right.$ and $45 \mathrm{~kg} \mathrm{~K}_{2} \mathrm{O}$ $\left.\mathrm{ha}^{-1}\right)$ and three levels of FYM $(0,5,10$ tonnes FYM ha ${ }^{-1}$ ) (Table 1). Treatments were randomized in each strip and replicated thrice. $\mathrm{N}$ was applied in three equal splits as basal and two top dressings at crown root initiation and maximum tillering; however, full basal dose of $\mathrm{P}$ and $\mathrm{K}$ was applied at the time of sowing. Test crop 'fennel' was grown during 2017-18. Twenty-four soil samples $(0-15 \mathrm{~cm})$ were collected from each strip before sowing of test crop fennel and analyzed for alkaline $\mathrm{KMnO}_{4}-\mathrm{N}$, Olsen's-P and $\mathrm{K}$ the ammonium acetate method.

\section{Results and Discussion}

\section{Establishment of fertility gradient}

Descriptive statistics of pre-sowing available soil nutrients in surface soil is presented in Table 2. Mean alkaline $\mathrm{KMnO}_{4}-\mathrm{N}$ of 221.02 , 232.42 and $242.47 \mathrm{~kg} \mathrm{ha}^{-1}$ were observed in strip I, II and III, respectively. Mean Olsen's-P values in strip I, strip II and strip III were 14.34, 16.10 and 23.48, respectively. The ammonium acetate method extractable- $\mathrm{K}$ of 206.67, 220.92 and $228.04 \mathrm{~kg} \mathrm{ha}^{-1}$ were recorded in strip I, II and III, respectively. From the data, it is obvious that mean value of the alkaline $\mathrm{KMnO}_{4}-\mathrm{N}$, Olsen's-P and the ammonium acetate method extractable-K was highest in strip III, followed by strip II and it was lowest in strip I. Within strip variation with respect to soil available nutrients can be explained by coefficient of variation. A marked fertility gradient was built up by application of graded levels of fertilizer and FYM. This indicates that, adequate variability with respect to soil available $\mathrm{N}, \mathrm{P}$ and $\mathrm{K}$ was developed before start of test crop experiment.

\section{Growth parameter attributes}

\section{Plant height and number of branches}

The data showed that integrated nutrient management significantly affected different growth parameters attributes of fennel viz., plant height $(\mathrm{cm})$ and number of branches of fennel viz., 35, 75, and 110 day after sowing. These result descriptive statistics of funnel growth parameters are presented in Table 3. During experimentation, the highest growth parameters were obtain strip III being fertile strip followed by strip II and the lowest in unfertilized strip I. Mean growth parameters of overall plots were viz., plant height $(\mathrm{cm})$, number of branches per plant, during all stages of growth of fennel viz., 35, 75, and 110 day after sowing. The mean value of strip I-height (cm) $(10.14,56.10,109.03)$, number of branches $(2.69,3.64,4.81)$, strip II - height (cm) $(12.07,67.13,117.05)$, number of branches $(3.11,4.72,5.65)$ and strip III height $(\mathrm{cm})(14.56,76.35,132.19)$, number of branches $(4.88, \quad 5.75, \quad 7.41)$. Growth parameters of funnel increased with the increase in application of fertilizer N, P and $\mathrm{K}$ and FYM. Increased Plant height $(\mathrm{cm})$, number of branches, fresh weight and dry weight (gm) with application of $100 \%$ NPK (recommended dose) of fertilizers or combined use of farm yard manure with nitrogen might have been resulted because of higher content of nutrients sufficient level that in turn gave higher yields. The findings are in agreement with those of Patashetti et al., (2002), Sankhyan et al., (2003) and Hattab et al., (2000). 
Table.1 Detailed N, P and K treatment combinations used for test crop experimentation

\begin{tabular}{|c|c|c|c|c|c|c|c|c|}
\hline \multicolumn{5}{|c|}{ Treatment Combinations } & \multicolumn{4}{|c|}{ Amount of nutrients } \\
\hline S.N. & $\mathbf{N}$ & $\mathbf{P}$ & $\mathbf{K}$ & FYM & $\begin{array}{c}\mathbf{N} \\
\left(\mathrm{kg} \mathrm{ha}^{-1}\right)\end{array}$ & $\begin{array}{c}\mathbf{P} \\
\left(\mathrm{kg} \mathrm{ha}^{-1}\right)\end{array}$ & $\begin{array}{c}\mathrm{K} \\
\left(\mathrm{kg} \mathrm{ha}^{-1}\right)\end{array}$ & $\begin{array}{c}\text { FYM } \\
\left(\mathbf{t ~ h a}^{-1}\right)\end{array}$ \\
\hline 1 & 0 & 0 & 0 & 2 & 0 & 0 & 0 & 10 \\
\hline 2 & 3 & 3 & 1 & 2 & 120 & 60 & 15 & 10 \\
\hline 3 & 0 & 2 & 2 & 2 & 0 & 40 & 30 & 10 \\
\hline 4 & 3 & 2 & 2 & 2 & 120 & 40 & 30 & 10 \\
\hline 5 & 2 & 1 & 2 & 2 & 120 & 20 & 30 & 10 \\
\hline 6 & 2 & 2 & 3 & 2 & 80 & 40 & 45 & 10 \\
\hline 7 & 1 & 1 & 2 & 2 & 40 & 20 & 30 & 10 \\
\hline 8 & 3 & 3 & 3 & 2 & 120 & 60 & 45 & 10 \\
\hline 9 & 0 & 0 & 0 & 1 & 0 & 0 & 0 & 5 \\
\hline 10 & 3 & 1 & 1 & 1 & 120 & 20 & 15 & 5 \\
\hline 11 & 2 & 2 & 0 & 1 & 80 & 40 & 0 & 5 \\
\hline 12 & 1 & 2 & 2 & 1 & 40 & 40 & 30 & 5 \\
\hline 13 & 2 & 1 & 2 & 1 & 80 & 20 & 30 & 5 \\
\hline 14 & 1 & 1 & 1 & 1 & 40 & 20 & 15 & 5 \\
\hline 15 & 1 & 2 & 1 & 1 & 40 & 40 & 15 & 5 \\
\hline 16 & 3 & 3 & 2 & 1 & 120 & 40 & 30 & 5 \\
\hline 17 & 0 & 0 & 0 & 0 & 0 & 0 & 0 & 0 \\
\hline 18 & 3 & 2 & 1 & 0 & 120 & 40 & 15 & 0 \\
\hline 19 & 2 & 0 & 2 & 0 & 80 & 0 & 30 & 0 \\
\hline 20 & 2 & 2 & 2 & 0 & 80 & 40 & 30 & 0 \\
\hline 21 & 2 & 2 & 1 & 0 & 80 & 40 & 15 & 0 \\
\hline 22 & 2 & 1 & 1 & 0 & 80 & 20 & 15 & 0 \\
\hline 23 & 2 & 3 & 3 & 0 & 80 & 60 & 45 & 0 \\
\hline 24 & 3 & 2 & 3 & 0 & 120 & 40 & 45 & 0 \\
\hline
\end{tabular}

Table.2 Descriptive statistics of available soil $(0-15 \mathrm{~cm})$ nutrients after soil fertility gradient experiment

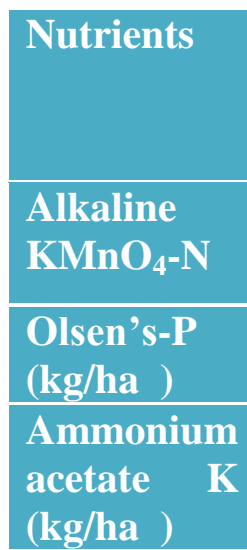

\begin{tabular}{|c|c|c|c|c|c|c|c|c|}
\hline \multicolumn{3}{|c|}{ Strip I } & \multicolumn{3}{|c|}{ Strip II } & \multicolumn{3}{|c|}{ Strip III } \\
\hline \multirow[t]{2}{*}{ Range } & Mean & SD & Range & Mean & SD & Range & Mean & SD \\
\hline & Sem \pm & $\mathrm{CV}$ & & Sem \pm & $\mathrm{CV}$ & & Sem \pm & $\mathrm{CV}$ \\
\hline $210-230$ & 221.02 & 8.44 & $215.86-250.50$ & 232.42 & 10.67 & $225.40-$ & 242.47 & 31.71 \\
\hline & 1.72 & 3.82 & & 2.18 & 4.59 & 265.44 & 6.71 & 13.08 \\
\hline \multirow{2}{*}{$13.44-15.12$} & 14.34 & 0.56 & $14.00-17.88$ & 16.10 & 1.46 & $21.44-25.56$ & 23.48 & 1.32 \\
\hline & 0.11 & 3.99 & & 0.30 & 9.09 & & 0.27 & 5.60 \\
\hline \multirow[t]{2}{*}{$192.48-214.17$} & 206.67 & 7.99 & $201.48-237.84$ & 220.92 & 11.59 & 213.89 & 228.04 & 7.75 \\
\hline & 1.66 & 3.87 & & 2.37 & 5.24 & 240.43 & 1.58 & 3.40 \\
\hline
\end{tabular}


Table.3 Descriptive statistics of funnel growth parameters

\begin{tabular}{|c|c|c|c|c|c|c|c|c|c|c|}
\hline Parameters & \multicolumn{3}{|c|}{ Strip I } & \multicolumn{4}{|c|}{ Strip II } & \multicolumn{3}{|c|}{ Strip III } \\
\hline $\begin{array}{c}\text { Plant } \\
\text { height }(\mathrm{cm})\end{array}$ & Range & $\begin{array}{l}\text { Mean, } \\
\text { Sem } \pm\end{array}$ & $\begin{array}{l}\text { SD } \\
\text { CV }\end{array}$ & Ran & & $\begin{array}{l}\text { Mean } \\
\text { Sem } \pm\end{array}$ & $\begin{array}{l}\text { SD } \\
\text { CV }\end{array}$ & Range & $\begin{array}{l}\text { Mean } \\
\text { Sem } \pm\end{array}$ & $\begin{array}{l}\text { SD } \\
\text { CV }\end{array}$ \\
\hline 35 DAS & $9.20-11.30$ & $\begin{array}{l}10.14 \\
0.186\end{array}$ & $\begin{array}{l}0.91 \\
9.01\end{array}$ & $\begin{array}{l}10.25 \\
13.70\end{array}$ & - & $\begin{array}{l}12.07 \\
0.19\end{array}$ & $\begin{array}{l}0.95 \\
4.51\end{array}$ & $12.60-16.70$ & $\begin{array}{l}14.56 \\
0.26\end{array}$ & $\begin{array}{l}1.29 \\
8.86\end{array}$ \\
\hline 75 DAS & $55.40-65.30$ & $\begin{array}{l}56.10 \\
2.87\end{array}$ & $\begin{array}{l}14.09 \\
25.13\end{array}$ & $\begin{array}{l}60.35 \\
72.40\end{array}$ & - & $\begin{array}{l}67.13 \\
0.81\end{array}$ & $\begin{array}{l}3.98 \\
5.93\end{array}$ & $67.65-84.20$ & $\begin{array}{l}76.35 \\
0.78\end{array}$ & $\begin{array}{l}3.81 \\
4.99\end{array}$ \\
\hline 110 DAS & $100.40-115.30$ & $\begin{array}{l}109.03 \\
1.00\end{array}$ & $\begin{array}{l}4.91 \\
4.51\end{array}$ & $\begin{array}{l}108.15 \\
125.50\end{array}$ & - & $\begin{array}{l}117.05 \\
.99\end{array}$ & $\begin{array}{c}4.870 \\
4.16\end{array}$ & $120.35-145.20$ & $\begin{array}{l}132.19 \\
1.47\end{array}$ & $\begin{array}{r}7.19 \\
5.44\end{array}$ \\
\hline $\begin{array}{l}\text { Number of } \\
\text { branches }\end{array}$ & & & & & & & & & & \\
\hline 35 DAS & $2.20-3.15$ & $\begin{array}{l}2.69 \\
0.06\end{array}$ & $\begin{array}{r}0.31 \\
11.54\end{array}$ & $2.85-$ & 3.95 & $\begin{array}{l}3.11 \\
0.09\end{array}$ & $\begin{array}{r}0.43 \\
13.96\end{array}$ & $4.30-5.45$ & $\begin{array}{l}4.88 \\
0.08\end{array}$ & $\begin{array}{l}0.40 \\
8.18\end{array}$ \\
\hline 75 DAS & $3.10-4.35$ & $\begin{array}{l}3.64 \\
0.69\end{array}$ & $\begin{array}{r}0.44 \\
12.13\end{array}$ & $4.10-$ & 5.25 & $\begin{array}{l}4.72 \\
0.08\end{array}$ & $\begin{array}{l}0.38 \\
7.99\end{array}$ & $5.20-6.70$ & $\begin{array}{l}5.75 \\
0.13\end{array}$ & $\begin{array}{r}0.66 \\
11.46\end{array}$ \\
\hline 110 DAS & $4.20-5.50$ & $\begin{array}{l}4.81 \\
0.09\end{array}$ & $\begin{array}{l}0.42 \\
8.86\end{array}$ & $5.00-$ & 6.90 & $\begin{array}{l}5.65 \\
0.13\end{array}$ & $\begin{array}{r}0.63 \\
11.18\end{array}$ & $6.50-8.15$ & $\begin{array}{l}7.41 \\
0.10\end{array}$ & $\begin{array}{c}0.49 \\
0.56\end{array}$ \\
\hline $\begin{array}{c}\text { Fresh weigh } \\
\text { (gm) }\end{array}$ & & & & & & & & & & \\
\hline 35 DAS & $20.70-28.30$ & $\begin{array}{l}23.72 \\
0.42\end{array}$ & $\begin{array}{l}2.04 \\
8.58\end{array}$ & $\begin{array}{l}26.40 \\
34.30\end{array}$ & - & $\begin{array}{l}30.40 \\
0.55\end{array}$ & $\begin{array}{l}2.69 \\
8.86\end{array}$ & $30.6-42.70$ & $\begin{array}{l}34.08 \\
0.70\end{array}$ & $\begin{array}{r}3.80 \\
11.15\end{array}$ \\
\hline 75 DAS & $57.35-65.60$ & $\begin{array}{l}60.16 \\
0.47\end{array}$ & $\begin{array}{l}2.28 \\
3.79\end{array}$ & $\begin{array}{l}60.20 \\
68.40\end{array}$ & - & $\begin{array}{l}63.38 \\
0.50\end{array}$ & $\begin{array}{c}2.43 \\
3.83\end{array}$ & $67.65-84.20$ & $\begin{array}{l}75.85 \\
1.04\end{array}$ & $\begin{array}{l}5.08 \\
6.70\end{array}$ \\
\hline 110 DAS & $100.30-109.35$ & $\begin{array}{l}105.08 \\
0.67\end{array}$ & $\begin{array}{l}3.30 \\
3.14\end{array}$ & $\begin{array}{l}105.15- \\
114.50\end{array}$ & & $\begin{array}{l}109.05 \\
0.61\end{array}$ & $\begin{array}{l}2.99 \\
2.74\end{array}$ & $113.35-140.20$ & $\begin{array}{l}126.61 \\
1.65\end{array}$ & $\begin{array}{l}8.10 \\
6.40\end{array}$ \\
\hline $\begin{array}{c}\text { Dry weight } \\
\text { (gm) }\end{array}$ & & & & & & & & & & \\
\hline 35 DAS & $8.20-12.40$ & $\begin{array}{l}9.98 \\
0.27\end{array}$ & $\begin{array}{l}1.33 \\
3.31\end{array}$ & $\begin{array}{l}10.40 \\
13.15\end{array}$ & - & $\begin{array}{l}11.24 \\
0.15\end{array}$ & $\begin{array}{l}0.73 \\
6.54\end{array}$ & $12.70-16.40$ & $\begin{array}{l}14.70 \\
0.29\end{array}$ & $\begin{array}{l}1.43 \\
9.73\end{array}$ \\
\hline 75 DAS & $22.40-25.15$ & $\begin{array}{l}23.81 \\
0.90\end{array}$ & $\begin{array}{l}0.93 \\
3.91\end{array}$ & $\begin{array}{l}23.25 \\
26.30\end{array}$ & - & $\begin{array}{l}24.39 \\
0.23\end{array}$ & $\begin{array}{l}1.15 \\
4.71\end{array}$ & $25.10-29.40$ & $\begin{array}{l}27.79 \\
0.24\end{array}$ & $\begin{array}{c}1.16 \\
4.16\end{array}$ \\
\hline 110 DAS & $36.45-\quad 40.30$ & $\begin{array}{l}38.39 \\
0.22\end{array}$ & $\begin{array}{l}1.10 \\
2.86\end{array}$ & $\begin{array}{l}37.15 \\
42.20\end{array}$ & - & $\begin{array}{l}39.36 \\
0.26\end{array}$ & $\begin{array}{l}1.27 \\
3.22\end{array}$ & $40.20-47.35$ & $\begin{array}{l}43.35 \\
0.51\end{array}$ & $\begin{array}{c}2.49 \\
5.74\end{array}$ \\
\hline
\end{tabular}

Note: DAS-Day after sowing, SD - Standard Deviation and CV - Coefficient of variation (Standard Deviation/Mean*100) in\%

\section{Fresh and dry weight/plant (gm)}

The data showed that integrated nutrient management significantly affected different growth parameters attributes of fennel viz., plant fresh weight and dry weight(gm) of fennel viz., 35, 75, and 110 day after sowing. These result descriptive statistics of funnel growth parameters are presented in Table 3. During experimentation, the highest growth parameters were obtain strip III being fertile strip followed by strip II and the lowest in unfertilized strip I.
Mean growth parameters of overall plots were viz. plant fresh weight $(\mathrm{gm})$ and plant fresh weight (gm), during all stages of growth of fennel viz., 35, 75, and 110 DAS. The mean value of strip I-fresh weight $(\mathrm{gm}) /$ plant $(23.72$, $60.16,105.08)$ and dry weight $(\mathrm{gm}) /$ plant- $(9.98$, 23.81, 38.39) strip II - fresh weight(gm) (30.40, $63.38,109.05)$ and dry weight $(\mathrm{gm})(11.24$, $24.39,39.36)$ and strip III - fresh weight(gm) $(34.08,75.85,126.61)$ and dry weight (gm) $(14.70,27.79,43.35)$. Growth parameters of funnel increased with the increase in application 
of fertilizer N, P and K and FYM. Similar results were observed by (Singh and Verma, 1999) and (Baboo et al., 1995)

It was observed that the recorded the higher Plant height, number of branches, fresh weight and dry weight increased with the increasing application of fertilizer N, P and K and FYM. So we can suggest STCR treatments with farm yard manure for eastern plain zone of Utter Pradesh for improvement of soil health and sustainable production.

\section{Acknowledgements}

The authors are grateful to Council of Science Technology, Lucknow (UP) for providing financial assistance through project during the course of investigation.

\section{References}

Baboo R, Rana S.N. (1995). Effect of cutting management, nitrogen and phosphorous on growth and yield of coriander (Coriandrum sativum L.). Indian Journal of Agronomy, 40(2):253-255.

Hanway, J. J. and Heidel, H., (1952). Soil analysis methods as used inIowa State College Soil Testing Laboratory. Bulletin 57. Ames, IA: Iowa State College of Agriculture 57: 1-31. Indian Farming 17: 43-45.

Hatabb, K., Natarajan, K. and Gopalswamy, A. (2000). Effect of organic and inorganic nitrogen combination on rice yield and $\mathrm{N}$ uptake. Journal of Indian Society of Soil Science. 48(2), 398-400

Jackson, M. L., (1973). Soil Chemical Analysis Prentice Hall of India Private Limited, New Delhi.
Olsen, S.R., Cole, C.V., Watanabe, F.S. and Dean, L.A. (1954). Estimation of available phosphorus in soils by extracting withlsodium bicarbonate USDA. Circular 939. Washington, DC: United States Department of Agriculture.

Pattanshetti, V.A., Agasiamani, C.A. and B, H.B. (2002). Effects of manures and fertilizers on yields of maize. Journal of Maharashtra Agricultural University. 27(2), 206-207.

Ramamoorthy, B., Narasimham, R.L. and Dinesh, R.S. (1967). Fertilizer application for specific yield targets on Sonora 64 (wheat). Indian Farming 17: 43-45.

Sankhayan, N.K., Bharat, B., Sharma, P.K. and Bhasin, B.: (2003). Effect of phosphorous, mulch and farmyard manure on soil moisture and productivity of maize in mid hills of Himachal Pradesh. Crop Research. 2(2), 116-117.

SBI. (2011). Statistics: Production of Major Spices. Spices Board of India, Ministry of Commerce and Industry, Government of India, New Delhi (http://www. indianspices.com).

Singh, N.B., Verma. K.K. (1999). Integrated nutrient management in rice-wheat crop sequences. Journal of Oryza. 36: 2, 171172.

Subbiah, B.V. and Asiza, G.L. (1956). A rapid procedure for the determination of available nitrogen in soils. Current Science, 25: 259-560.

Walkey, A. and Black, I. Armstrong (1934). An examination of the Degtjareff method for determining soil organic matter and a proposed modification of the chromic acid titration method. Soil Science, 37(1): 29-38.

\section{How to cite this article:}

Singh, Y.V., D.K. Srivastava, Pavan Singh, S.K. Varma, A.K. Kanthle and Mishra, D. 2018. Effect of Integrated Nutrient Management on Growth Parameters of Fennel (Foeniculam valgare Mill.) in Inceptisol. Int.J.Curr.Microbiol.App.Sci. 7(03): 1067-1072. doi: https://doi.org/10.20546/ijcmas.2018.703.127 